\title{
On Improving the Effect of the Probity Education for College Students in the Practice of Poverty Alleviation
}

\author{
Weiqin Yuan \\ Chongqing Center for Research on Clean Government \\ Chongqing Technology and Business University \\ Chongqing, China \\ 1692668565@qq.com
}

\begin{abstract}
It is necessary to improve the actual effect of the education, so that most of the students who receive probity education can remain clean after graduation. For this reason, it should be emphasized that the key is not abstract theory, but experiential practice. We can try to make students accept probity education in poverty alleviation practice. Appropriate practical identities should be given to college students in the practice. Each college student can get the guidance of the appointed three teachers. The three teachers include a staff member of research institutions of anti-corruption in colleges, a poverty alleviation agency staff and a supervisory agency staff. The students should formulate the education plan and implement it under the guidance of the three teachers. The most important thing in the plan is to make clear the tasks. The tasks are cultivating clean values, enriching honest knowledge, and training anti-corruption skills.
\end{abstract}

Keywords-college students; probity education; actual effect; poverty alleviation; practice

\section{INTRODUCTION}

It is one of the missions for the research institutions of anticorruption in colleges to carry out the probity education for college students. "The current probity education ignores and misreads the 'real individual', therefore there is a tendency of idealization, cognition and abstraction in the education which weakens the charm, persuasiveness and attractiveness of the education”. [1] The tendency results in the fact that the actual effect of probity education is not good in many universities. In order to improve the effectiveness of probity education, scholars have put forward some plans. A suggestion is made to create a new platform for probity education based on WeChat function. [2]Another suggestion is that we should establish the principle of the first classroom teaching combined with the second classroom teaching, and combine the public teaching with professional teaching. [3]These suggestions have noticed the use of the existing college resources and the new media in the new era to carry out probity education, but still fail to pay attention to the practicality of education. Of course, it is not entirely unnoticed that probity education should pay attention to practice. Professor Xianqiu suggested that probity education should be integrated into family life, college life and daily life. [4]Professor Xuemei claimed that theory should be combined with practice; cognition should be combined with practice. [5] On the basis of the concept of the two professors, this paper further argues that in order to improve the actual effect of the education, we can try to let students accept probity education in the social practice, such as poverty alleviation practice.

\section{Practice Is AN EfFEctive Way}

Practice is an effective way to improve the effectiveness of probity education for college students.

\section{A. Probity education for college students is an important task}

As the key research base of the humanities and social sciences in colleges, it is one of the missions for the research institutions of anti-corruption in colleges to carry out the probity education for college students. Ministry of Education's Opinions on Carrying out Probity Education in Colleges, Middle Schools and Primary Schools requires: "We will launch a probity education in all the universities, middle and primary schools in China from 2007.” [6]Management Methods for Key Research Bases of Humanities and Social Sciences in Colleges regulates: One of the five tasks of the key research base of the humanities and social sciences in ordinary colleges is to cultivate talents. [7]Therefore, as the key research base of the humanities and social sciences in colleges, the research institution of anti-corruption should also carry out the probity education. In fact, these research institutions have the advantage of probity education because they have a lot of research results about anti-corruption which can be translated into teaching content.

\section{B. The Purpose of Probity Education}

The purpose of probity education for college students includes cultivating clean values, enriching honest knowledge, and training anti-corruption skills.

Firstly, the concept of value affects the direction of action. The concept of value is a human judgment of right or wrong, choice of interests, which guides the behavior motivation and affects the direction of action. Without a clean value, it is easy to corrupt people in the face of temptation. Therefore, it is necessary to cultivate a clean value. 
Secondly, knowledge is not only the experience of human exploration of the world, but also a tool for human to continue to explore the future world. The number of clean knowledge has a profound influence on the probabilities of crossing a clean red line in the future world.

Under the same circumstances, the more clean knowledge a person has, the less probability he is to corrupt. Therefore, it is necessary to enrich the clean knowledge for college students.

Finally, skills affect the ability of people to do something. If a person has only the clean value and the clean knowledge without clean skills, he is like a driver who knows perfectly well it is not right to run through a red light, but has no ability to stop the car. If students do not master the skills to keep clean, after graduation to join the social flow, pressures or temptations may destroy their integrity consciousness. Therefore, it is necessary to exercise the skills to keep clean of the educated.

\section{Practice Is the Fundamental Way}

Practice is the fundamental way to enhance the effectiveness of clean education. As China's Southern Song Dynasty poet Lu You said, "The knowledge you get from paper is superficial, and you need to do it to understand it really. "Out of practice, the effects of learning are abstract rather than empirical, hypothetical rather than validated, and therefore non-persistent and unstable. Integrity of values, honesty knowledge can only be validated in practices which make students truly convinced. And, social practice is an effective training ground for clean skills.

\section{Why Do We Choose the Poverty AlLEVIATION PRACTICE AS THE PATH}

\section{A. Being Clean Is Very important to Poverty Alleviation}

Firstly, corruption in poverty alleviation violates the human rights of the poor. Corruption distorts the implementation of pro-poor policies, and poor people can't get poverty alleviation funds in time so that poverty can't be eliminated on schedule and the poor people's rights to subsistence and development may be infringed upon.

Secondly, corruption in poverty alleviation undermines the credibility of the Chinese government to protect human rights. China has joined International Covenant on Economic, Social and Cultural Rights(ICESCR). The eleventh article of ICESCR stipulates that: "The States Parties to the present Covenant recognize the right of everyone to an adequate standard of living for himself and his family, including adequate food, clothing and housing, and to the continuous improvement of living conditions. "Corruption impedes the isolation of the poor from poverty and undermines the Chinese government's active performance of the ICESCR's human rights guarantee.

Thirdly, corruption in poverty alleviation can also hinder the fulfillment of the solemn promise of the Chinese Communist Party and tarnish the image of the Communist Party of China. "Letting the poor and poor areas enter the welloff society in an all-round way with the whole country is a solemn promise of our party."[8] Corruption in poverty alleviation threatens the realization of the goal of poverty alleviation and makes the Communist Party's promise unfulfilled.

\section{B. Corruption In Poverty Alleviation Still Exists}

There is still some corruption in poverty alleviation at present. These corrupt phenomena have different shapes: making false or excessive reports of the state funds for poverty alleviation, posing as others to receive poverty alleviation funds, claiming for fictitious expenditures in poverty alleviation, preference for loved ones and friends. For example, since July 2016, discipline inspection and supervision organs at all levels in Guangxi have found 8, 653 corruption cases in the field of poverty alleviation and punished 5, 670 people. [9]

\section{HOW DO We CARRY OUT THE PROBITY EDUCATION IN THE Practice of POVERTy AlleViation}

\section{A. Appropriate Practical Identity and Designating three teachers}

Appropriate practical identities should be given to college students in the practice of poverty alleviation. These identities may be poverty alleviation agencies, the poor people or the third parties with some direct interests. Other identities may also be available, such as staff members of discipline inspection departments who oversee poverty alleviation, staff members of public information departments tracking down poverty reduction work, and independent observers participating in practice. Similar to actor acting, college students should think of the integrity problems from the role which they play, but not from themselves as college students.

Each college student can get the guidance of the appointed three teachers. These three teachers include a staff member of research institutions of anti-corruption in colleges, a poverty alleviation agency staff, a supervisory agency staff. Their advantages are respectively rich in probity theory, familiar with the practice of poverty alleviation, or good at the practice of anti-corruption.

\section{B. Making an Education Plan and Implement It}

The students should formulate the education plan and implement it under the guidance of three teachers. The most important thing in the plan is to make clear the tasks. This article argues that the tasks of probity education in poverty alleviation practice are cultivating clean values, enriching honest knowledge, and training anti-corruption skills.

First of all, the students and teachers should think about how to nurture and deepen the clean values concept in poverty alleviation practice. Under the guidance of three instructors, the college student may think about the motivation of corruption in combination with his roles. The motivation may be to make up the income gap between oneself and the "rich man", make up for the difference between his normal income and his contribution, or meet the needs of better life, satisfy his vanity, take vengeance on the society. The motivation may be also just because of hating the lazy people in the poor, and so on. The instructors should guide the college students to look at these ideological motives correctly. Students need to understand that 
the standards of judging a person's social value are not only how much money he has. On the contrary, if the money is illegally obtained, it is a disgraced thing and he is subject to legal sanctions. Therefore, it is respectful to be clean and not to get rich through corruption. If a person wants to make more money, he should be a businessman who has the entrepreneurial spirit of adventure and the ability to take advantage of market opportunities rather than a civil servant. In fact, the income of the civil servants is stable very much, while the income of businessmen is elastic, and businessmen can be in huge debt when they fail.

Secondly, under the guidance of the instructors, college students may think about how to enrich their honest and clean knowledge with their roles. On the one hand, the may study universal knowledge of preventing and punishing corruption, include relevant legislation, inner-party laws and regulations, and government regulations. Such as the United Nations Convention Against Corruption, the criminal law on the duty crime, the government information disclosure regulations, the prohibition of conflict of interests. It is necessary to think about the combination of poverty alleviation and these provisions. On the other hand, they may learn more about the special clean documents in the field of poverty alleviation and guide the work on poverty alleviation. There are many special documents about anti-corruption. They are formulated by the Office of the Central Committee of the Communist Party of China, the Office of the State Council, the National Development and Reform Commission, the Ministry of Finance, the National Poverty Alleviation Office, the Ministry of Civil Affairs, the National Committee on Ethnic Affairs, the Housing and Urban and Rural Construction Committee, the Ministry of Agriculture, or the Forestry Bureau, etc. For example, Measures for the Administration of Funds for Poverty Alleviation in the Central Government regulates: "The information of capital policy documents, management system and the result of the allocation of funds should be open to the society in time and accept the supervision of the society. "[10] The Notice on Strengthening and Improving Transformation of Rural Crisis Houses for the Poor Households in the Book and Other Key People requires to prevent the subsidy from being taken fraudulently and repeatedly applied for, and regulates: "It is forbidden for grassroots staff to accept a banquet, encroach on the subsidy, make trouble for the applicant and ask for the benefits during the process of handling subsidies.”[11] In fact, the relevant documents include not only the provisions of the central department but also the provisions of local governments at all levels and their departments.

Thirdly, the students should exercise their own skills of anti-corrosion and refusing to corruption in the practice of poverty alleviation. These skills include the skills to resist the temptation of money or sexual seduction, to resist the illegal intervention by superior leaders, relatives and friends. By the exercise, the students should know very accurately which people they can't meet with or make friends with, which occasions they can't attend, which dinner they can't go to. By the exercise, they should also understand which of the working parts of poverty alleviation and which posts are prone to corruption. Furthermore, these students can carefully study the corruption cases in the corresponding fields, find out the positions and the corresponding powers involved, find out the risk points of corruption, and put forward the supervision and restriction measures to prevent corruption.

\section{SUMMARY}

The effects of many probity educations are not good now. To take exercise in poverty alleviation practice is an effective way to improve the effectiveness of probity education. These students may be equipped with three experts as mentors and make plans to cultivate clean values, enrich honest knowledge, and train anti-corruption skills.

\section{ACKNOWLEDGMENT}

This article is supported by research project of the Chongqing Institute of Higher Education (No. CQGJ15033C) about Research and Practice of the Research Institutions of Anti-Corruption in Colleges on the Construction of the Probity Education Model Curriculum, supported by CTBU 's research projects about Strengthening the Supervision and Restriction on Power (No. 1456012)and about the Construction of the Model Course (No. 2015209) . It is also supported by the project of Research on the Illegal Loss of Government Funds for the Elderly Care Services with the PPP Model, which is funded by the Humanities and Social Sciences Project of the Chongqing City Education Committee (No. 16SKJD24). I am very grateful for the supports of these projects.

\section{REFERENCES}

[1] Zhiya Zhou, Xiaowei Peng. An analysis of the realistic predicament and countermeasures of China's probity education [J]. Theory \& Reform, 2015 (01): 184. (in Chinese)

[2] Zhi Wang, Peng Huo. The dilemma and countermeasures of the probity education for college students in the WeChat era[J]. Party Construction \& Ideological Education of the School, 2017 (02): 38. (in Chinese)

[3] Chengxiu Bian, Xiaoming Deng, et al. The problems and countermeasures of the probity education for college students [J]. Party Construction \& Ideological Education of the School, 2016 (12): 85. (in Chinese)

[4] Xianqiu Tang. The life mark of traditional probity education and its modern enlightenment[J]. Qilu Journal, 2017 (03): 65. (in Chinese)

[5] Xuemei Tian. "Four combinations" to promote probity education for college students[J]. Research on the Education of Thought, 2016 (04) :83-85. (in Chinese)

[6] Ministry of Education of People's Republic of China (2007). Ministry of Education's Opinions on Carrying out Probity Education in Colleges, Middle Schools and Primary Schools. Beijing. 2007, No. 4. (in Chinese)

[7] Ministry of Education of People's Republic of China (2006). Management Methods for Key Research Bases of Humanities and Social Sciences in Colleges. Beijing. 2006, No. 3. (in Chinese)

[8] Jinping Xi. Winning the decisive victory of building a well-off society in an all-round way and seizing the great victory of socialism with Chinese characteristics in a new era-Report on the 19th National congress of the Communist Party of China. Beijing: People's Publishing House, 2017:47. (in Chinese)

[9] Guangxi Commission for Discipline. Strengthening efforts to tackle the problems of corruption and style of work in the field of poverty alleviation[online]. Available from:

[10] http://www. ccdi. gov. cn/yw/201712/t20171205_113143. Html [Accessed: 6 Dec. 2017]. (in Chinese) 
[11] Ministry of Finance of the People's Republic of China(2017). Measures for the Administration of Funds for Poverty Alleviation in the Central Government. Beijing. 2017, No. 8. (in Chinese)

[12] Housing and Urban and Rural Construction Committee of the People's Republic of China, Ministry of Finance of the People's Republic of
China, the National Poverty Alleviation Office of the People's Republic of China(2017). The Notice on Strengthening and Improving Transformation of Rural Crisis Houses for the Poor Households in the Book and Other Key People. Beijing. 2017, No. 192. (in Chinese) 